Ousmane M. Tandina

Ousmane M. Tandina teaches in the Department of Modern Languages, at University of Niamey, Niger. He is in charge of courses on the Traditional African Epic, African tales and African drama.

E-mail: otandina@refer.ne

\section{The joys or misfortunes of love in the courtly epics of Djado Sékou}

\title{
The joys or misfortunes of love in the courtly epics of Djado Sékou
}

Diado Sékou, a professional storyteller, is one of the most celebrated griots in Niger. He has a predilection for everything that deals with the imaginary and dreams. His audience is fond of love stories, which he considers a superior form of literature. Love in the narratives of Djado Sékou, it is a founding and fundamental theme. The theme of love permeates Niger's courtly epic as the narratives "Labdedjo" by Tinguizi and "Garba Mama" by Djéliba Badjo well exemplify. Djado Sékou is one of the storytellers who have sung the most of love, in particular, the love of men for one woman, Awli Djawando. Along with Lobbo Soga, Takadé Waldé, Fatumata Bidani and Sipti Diembel, Awli Diawando has entered the pantheon of Niger's celebrated muses. However, if Diado Sékou sings of love, the joy and revival of individuals who experience "dizziness," it is noteworthy that his songs also often originate from suffering and the misfortunes of love. This essay explores constituting themes Djado Sékou's narrative repertoire: love stories as fairy tales, ecstasy and loss, metamorphosis of places and names and journeys. Key words: Djado Sékou, courtly epic, love, Niger.

Characterized by structures underscoring the events affecting the fate of the characters, the courtly epic is "a poem organizing the hero's trajectory according to the changes of a whimsical fate favouring encounters, creating separations, and involving the fantastic and love" (Suard, 1993: 80). ${ }^{1}$ This type of literature produced by griots (bards) appeared in Niger by the end of the $18^{\text {th }}$ century during the Jahillya or the pre-Islamic period; a period dominated by the Ceddo dynasty, during which valiant mounted warriors celebrated war and violence as the only legitimate means of demonstrating bravery, military might or magical power.

The theme of love permeates Niger's courtly epic "by a thousand dream roads," as the narratives "Labdedjo" by Tinguizi and "Garba Mama" by Djéliba Badjo well exemplify. Djado Sékou is one of the storytellers who have sung the most of love, in particular, the love of men for one woman, Awli Djawando. ${ }^{2}$ Along with Lobbo Soga, Takadé Waldé, Fatumata Bidani and Sipti Diembel, Awli Djawando has entered the pantheon of Niger's celebrated muses. 
Djado Sékou's audience is fond of love stories, which, as a professional storyteller, he considers as a superior form of literature. It is therefore not surprising that he gives them pride of place in the epic narratives examined here.

Djado Sékou sings of love, drawing inspiration from the joy and rejuvenation of those who experience its spell of "dizziness". Yet it can be noted that his songs are also inspired by the suffering and "misfortunes of love". Indeed, both as an emotion and as a notion, "the misfortunes of love" seem to be the centre of his imaginary universe and an inexhaustible source of inspiration for Djado Sékou. Some of his epic narratives explore the topic of the relentless quest for love and pleasure. This is illustrated in Takadé Waldé's courtly epic entitled "Bubu Ardo Galo", concerning the "the unsurpassably beautiful Fulani woman". Another such example can be found in "Hamma Bodedjo Paaté", in the guise of the extremely wealthy Fatumata Bidani Simbiri , "with skin so light, eyelashes so dark, a neck so graceful, a waist so slender, hips so perfect, the whites of her eyes so immaculate, not red like the eyes of pigeons". ${ }^{3}$

In other narratives such as "Awli" and "Mamudu Djawando", the misfortunes of love appear in a more familiar way. A griot challenges the men of the Djawando Fulani community by proposing to compose a particular musical tune for whomever among them will accept to jump into a pit in filled with lances, their poisonous spikes turned upwards. For three weeks, no one dares to meet the challenge. Finally, the young and extremely beautiful heroine, Awli Djawando steps forward; she accepts and rises to the challenge, to the displeasure of the men.

To test the bravery of the disconcerted men, she proposes a trial by challenging any of them to stay for a week in his hut, without food or water. As a reward, she will marry the winner. Only Mamudu Jawando, a foreigner to the country, is successful. But the griotte of Awli's chambermaid and the people of the village conspire to disqualify him. Powerless against their calumny, Mamudu plants a knife in his stomach and disembowels himself to show Awli that indeed they contain no food. He did not drink the milk placed in the hut; a calf spilt it. The conspiracy exposed, Awli weeps for Mamudu. She organises a second trial for her suitors: she will only marry the one who can stand her persistent and regular laments. Another Jawando meets this challenge. Their love for one another becomes so strong that after consummating their marriage, they agree, out of the excess of their passion, to set fire to their bridal hut and die together. The griot presents the suicidal extremes of the two heroes as a tragic virtue. 
The misfortunes of love are also represented in "Lobbo Soga," a narrative centring on a young couple whose happiness is disturbed by a king. Though a love narrative like "Mamudu", "Sombo Soga" is less austere. Despite the difficulties involved in the hero's adventures, the story ends rather happily. Lobbo Soga is so exceptionally beautiful that anyone who sets eyes on her falls in love. However, as she is extremely proud, she scornfully rejects all her suitors. Somba Soga, a young man of angelic beauty, is the only man she appreciates. The two youths love each other passionately, but refusing their romance, the king of Sâ abducts the girl and marries her. As a result, Sombo and Lobbo Soga can only meet or talk to each other in secret, through a hole Lobbo makes in a wall in the king's palace.

However, one day, the king finds them out. Resolved to remain with his lover, Sombo refuses to flee as Lobbo advises him. He remains in place until dawn, playing a musical tune he has composed for his beloved. Thinking the music he heard was played by a griot, the king summons all the moolo (lute) players of the village the next day and threatens to kill them all unless they reveal the identity of the one who was with his spouse the night before. A griot denounces Sombo Soga and makes it clear that this insolent musician is not a griot.

Summoned by the king, Sombo arrives at the palace and finds Lobbo sitting, magnificently dressed. Looking at each other, the two lovers are suddenly overcome by violent despair when the king asks his courtesans the fate he should reserve for Sombo. Some suggest that he be burned alive, others that he be cut him into pieces with a razor, still others that he be tortured viciously.

A wise man of the village takes the floor and asks the king to pardon Sombo, to refrain from destroying such a beautiful couple. He argues that this is the only way the king will overcome his bitterness, because in any case, he will never manage to erase the insult. On the contrary, insists the wise man, by allowing the young couple to marry, he will enhance his reputation.

"Gorba Dicko" also concerns the joys or misfortunes of love. As they sit chatting one night, a group of valiant soldiers take turns relating memories of past exploits. Suddenly, an upstart sharply addressing Gorba Dicko, asks why he has remained silent all this time, comparing him to a braggart who dares not admit he has experienced fear at least once in his life, and challenging him to go and abduct "the black wife" of a king reputed for his cruelty. To show his bravery, Gorba Dicko accepts to meet the challenge, and sets out to steal the woman from her 
husband to the great displeasure of all the courtesans and against their will.

This account clearly reveals the injuries of love that comprise the setting of courtly epic narratives. We note, for instance, anguish in the face of the unknown and the inaccessible regarding the beloved in "Lobbo Soga," or the pain of separation in "Gorba Dicko," or still the feelings generated by pride mingled with love in "Awli Djawando."

Djado Sékou's characters are profoundly embedded in the history and society of their time. They experience difficult love relations that are sometimes tragic, often ending in failure. The most disastrous of these failed romances is perhaps the one involving Mamudu, Awli's first fiancé, in "Awli Djawando."

In "Sombo Soga", Djado Sékou portrays a budding love, presents characters evolving between the beginning of love and separation, and ends his stories with an ultimate encounter. In "Awli" he rather concerns himself with mature, adult love. Awli and her second fiancé, Djawando, experience this kind of love. Living together, no major or apparent obstacle seems to disturb their relations. However, like the characters of the great myths of passionate love, Awli and Djawando invent an obstacle: "without impediments to love, there is no 'romance'," writes Denis Rougemont, explaining that in the Western tradition, the interest of romance novels lies in "the variations and delays of passion" (les variations et les retards de la passion), in "its crescendo leading up to catastrophe" (son crescendo jusqu'à la catastrophe, Rougemont, 1979: 54).

In "Awli Djawando", Awli therefore plays the role of an embarrassing character. She provokes suffering for the couple and leads it to death, thus closing the narrative; a narrative, which illustrates Aragon's words about "a happy love moving towards suicide" (un amour heureux qui va au suicide, Brochier, 1994: 40).

To the extent that the nature and substance of love stories vary according to the emotions involved and the type of relationship - sometimes idealized or sublimated, and other times demystified or desacralized, I will hereafter try to show certain aspects of the joys or misfortunes of love in Niger's courtly epic. I will try to highlight the different portraits of the poetics of love in Djado Sékou's work. As a comprehensive and precise study reveals, this sentiment also seems to shape Djado Sékou's style and to produce blooming images and metaphors, including the sweet reveries and renewal related to love as well as the suffering and pain it often generates. 
For Djado Sékou, love is neither a concept nor an abstract notion. It is reality lived with a carnal being. Therefore, it truly opens into the sensitive and palpable world. However, at the same time, it also suggests the world beyond concrete reality. It favours the deployment of the imaginary and evoked the presence of the unreal, of dreams or of an enchanted world.

As a source of enchantment, marvel, and surprise, love indeed seems to generate a magical process. In his narratives, Djado Sékou defines it as a state of confusion between reality and fantasy. In contact with love, space and time are therefore not just "felt by the heart", but also perceived as a dream.

Time is a woman in Djado Sékou's epic narratives, because Fatumata Bidani, Lobbo Soga, and Awli Djawando shape men's destiny. Where there was originally only a juxtaposition of moments without any clear direction, they create links and movements. They allow men to position themselves accordingly, to experience eventful action. In "Hamma Bodedjo Paaté", Djalé Hamma Bodedjo Paaté encounters a young girl named Fatimata Bidani. Her beauty is so extraordinary that all the great and renowned heroes wish to marry her. She is also extremely wealthy, but has neither father nor brother, and is still single.

Only her mother is still alive, but she is so whimsical that she dares to challenge the son of the king of Sâ, dreaded by all other kings. She creates a scandal by going to the market of Sâ where she beats the prince's dog. Everybody knows that it is forbidden to give even the slightest tap to the prince's dog. As a punishment, the mother is beaten up and her head shaved. She asks her daughter to avenge her. Fatumata Bidani goes to seek help from all the heroes who in the past wanted to marry her. However, all of them ask her to give them time to get ready: some request two years, others six months, and the less cautious two months. At a loss, Fatimata Bidani abandons them and goes to Djalé Hamma Bodedjo Paaté, who consents to confront the powerful king of Sâ right away, and he defeats him.

Besides punctuating the hours and minutes, women also give meaning to the lives of men that is to say direction and deep significance, a raison d'être. As a result, Djado Sékou's male characters always feel that women are the very incarnation of fate. They perceive their amorous encounters as the major event, one that almost irrevocably determines and alters their existence. In "Awli Djawando", Djado Sékou portrays love as ineluctable: something a man cannot escape; becoming something like a tragic hero in the grips of fate. This is the case of Awli's two 
fiancés, as well as Sipti Diembel in "Labdedjo". ${ }^{4}$ Shortly after the death of her husband, a Gourmantché chief who had challenged a white district officer, she decides to imitate him:

She took the knife

and planted it between her breasts.

She planted it with such force

that the knife pierced through.

Then using her two hands,

she withdrew the knife from her breast

and planted it again, under her navel.

She could no longer withdraw it.

She fell on the ground

Before the horsemen could come to her assistance,

she was already lukewarm.

She was buried with her husband in the same grave in Koola. ${ }^{5}$

This act reveals a world in the process of disintegration, where the nobility, guardian of traditions, is pricked into refusing colonial. It is also an act of love, love between two individuals who have sworn faithfulness to each other: "she was buried with her husband in the same grave". Like man, the epic narrative seems incapable of avoiding love. Almost all epics from Niger evoke love. However, if love is often represented as a sort of internalized fatality, it sometimes appears under brighter auspices and ends happily. The theme of love is not always negative or fatal in Djado Sékou's narratives. In his "Lobbo Soga" and "Garba Mama" love "is on the other side of the mirror, at the converging point of dreams" (se trouve de l'autre côté du miroir, au point de convergence des rêves, Sur, 1966: 80).

\section{Love stories always resemble fairy tales}

Love matches assume a dreamlike character. They provoke "dazzling", sensations of "illumination", to use Jean Sur's words (1966: 86). Couples in this case evolve beyond reality, in a universe marked by fantasy, and live an event so forceful and so unexpected that some characters cannot believe it, thinking they are living a fairy tale that will fade before dawn. This is the case with Mamudu, whose dreams of marriage collapse following a betrayal: to conquer Awli, Mamudu sets out to seek marabouts (Islamic faith authorities) and medicine men capable of helping him resist hunger and thirst for eight days. (Thanks to their intervention), when pressed by nature's call all he has to do is caress his 
stomach; magically an old man answers his need by proxy. Maudu Djawando eats three magic flat cakes. Arduously, he arrives at Awli Djawando's and asks that marriage be celebrated without further delay, because he has not come to stay forever. The test is explained to him. Sitting on his seat, Mamudu Djawando crosses his legs: "and the eight days went by without his uncrossing them, or even thinking of standing up: neither for thirst nor hunger, neither for any other need that he may have felt."

After the eight days, a clamour rose. People were saying, Mamudu Bokkum has passed the eight-day test. The young girl was asked to go have her hair braided. But later on, the brave men of the village consulted one another and plotted against Mamudu the foreigner to oust him. Dumbfounded, Mamudu then took a knife and stuck it in his stomach. His intestines spilled out, and he severed them.

Mamudu's feat may not be justified simply by his sense of honour, as one may believe. It also stems from fantasy, the love for a real and living woman, a love in which every instant, the loved one fills the spirit and heart: "a person in love is filled by the image of the one he loves attentively and continuously," explains Stendhal (1989:311). ${ }^{7}$ Thus Awli, or her image, takes possession of the instances that make up Mamudu's life, with such a great ease that he is often prey to idleness. He abandons everything for the sake of conquering her.

This scene may be a parody of a failed fairy tale, but Djado Sékou's work contains other scenes or stories that may be compared to fairy tales with a happy ending. This is the case of "Sombo Soga", which ends in the classic manner: the king gives Sombo a gleaming gown, his own ceremonial garment, his magnificent steed, his wonderful messenger, a slave, and his oldest slave at that. Then he asks Baïdari to help Sombo and Lobbo mount.

Everywhere loud shouts rose

calling for people to come out and witness a novel spectacle in three parts:

Sombo the majestic,

Lobbo the beautiful,

the messenger,

and to keep watching them until they reached their destination. ${ }^{8}$

This narrative nonetheless reveals that Djado Sékou gives great importance to surprise, the capacity for astonishment and wonder. 


\section{The metamorphosis of places and names}

Djado Sékou endows his characters with a great and even unlimited capacity for metamorphosing the real, for doubling it with the imaginary. For instance, as soon as two lovers meet, everything surrounding them takes on a magical aura. The "love settings" and places change. In "Awli", the magic of love opens onto a concrete universe, first in the bush where the lovers meet, then in a hut where they make love. Thereafter, metamorphosis allows for the rebirth of a metaphysical spirit, when the lovers set fire to the hut in order to be consumed alive. A taste for the unreal, the imaginary is aroused, for everything that is beyond the real world. The hut is burning. Awli sets fire to its four corners and joins her fiancé, the second after Mamudu's death, and the couple no longer wants to leave this enchanted forest where the man plays moolo and the woman claps her hands to the rhythm of the instrument. Djawando is the name of Awli's new fiancé, whose vision of the world is transfigured by the presence of the woman. In her company, he is carried away without being disturbed by the fire. Perceived as a genuine magician whose body is compared to nature itself, the beloved wife is at the origin of this fairy tale. Djado Sékou reveals this in a superb passage where words retrieve their poetic force:

They [Awli and Djawando] chatted till the approach of dawn;

she asked him to put the moolo aside,

he put it aside;

the young girl lay down

on her back,

she untied the end of her cloth

threw it away from her;

she untied the other end and threw it on the other side

and then she invited the man to see that she is a virgin.

The man leapt into action

and found indeed that she was a virgin.

She told him: "Do you admit that you have seen

what no other man has seen before?"

He said: "True, you are a virgin among the virgins of this earth." 9

Awli sets fire to the hut after the sexual act. Is this to test Djawando's bravery or the depth of his love for her, or is it because of her taste for the absolute and for perfection? I shall return to this later. Or rather, is this an opportunity for the storyteller to show off his virtuosity, the fertility of his creative imagination? Djado Sékou's particular style as a griot leads 
him to say out loud what members of the upper social strata dare not talk about. No noble person is allowed to utter words of this kind, considered indecent, without being blacklisted, according to Zarma or Fulani social ethics.

Present in the different elements, in water as in fire, woman is the synthesis of a marvellous, natural and original world. In Djado Sékou's work, the character in love easily yields to the power of the imaginary. Reverie influences the choice of names characters receive. These include popular names describing beauty. For instance, Takaldé Waldé means "Warm Embrace" while Lobbo means "Beautiful" in Fulfulde. The griot's reverie on Awli's name finds its source in a literary reminiscence - traditional epic revives historical memory:

Awli Dawando was a heroic woman.

All the regions whence she heard

her ancestors had been chased,

she burned them down. ${ }^{10}$

When a hero hears Awli's name for the first time, he is convinced that this evocation will lead him to the woman he of his dreams, the prototype of the brave woman: the incarnation of courage and love.

If the power of the name suffices to summon up the beloved woman's presence in the imagination, this is perhaps because her name - or the one her suitor gives her in secret - is a a negative or a reflection of her true self. The Homeric epithet "Soga", which affixes Lobbo and Sombo means "Beauty". Thus, the names "Sombo the Beautiful" and the "Lobbo the Beautiful" imply that these two individuals were made for each other, like Romeo and Juliet or Tristan and Isolde.

For Djado Sékou, the name given to the beloved must therefore be an efficient representation. Awli can only take a valiant man for a husband, which is why she asks for her suitors to be informed that now she is ready for marriage; but that the one who wishes to take her as wife must prepare himself accordingly. She maintains that she must be married in the same manner that she acquired her reputation, because any man who wishes to marry her will have to spend eight days in her mother's hut, without food or water.

Hence, Djado Sékou's work deals with the poetry and magic of names. As a storyteller, he gives great importance to naming. However, the name is not the only pathway to dreams in Djado Sékou's narratives. The face of beloved one - unpleasant as it may be at first sight and her voice also triggers the imagination and sends her lover into 
reverie. In "Hamma Bodedjo Paaté", Fatumata Bidani never shows herself to her suitors until the day she asks them to avenge her mother against the powerful prince of Sâ. Until then, they are only allowed to hear her voice and see her ring, which she sends them via her little slave girl.

In "Awli Djawando", Awli's voice is the only thing that men dread. It is a warm, deep, and inflexible voice in which she asserts her power over men. She scares away suitors who have no courage, whose only resource is sweet talk. As the griot puts it, when she shouts her suitors menstruate.

Beside the name, the voice and tone, differing from one person to another, are also important attributes, and perhaps the principal pathways into the land of amorous dreams in Djado Sékou's narratives. Of course, most characters are sensitive to the voice of their beloved. But the voice also launches lovers into the universe of the imaginary. This is especially true in the case of Sombo Soga when he enters the closed tower where the King has locked his sweetheart.

Lobbo, as soon as she heard Sombo's voice

Sombo, as soon as he laid his hand on Lobbo,

as soon as his finger brushed her,

caressed her,

the emotion he felt stopped his breath. ${ }^{11}$

The lovers are, for one another, inroads into fantasyland. As such, they become dream creations or creatures, imaginary beings sprung from the idealization and "crystallization" processes of love, to use Stendhal's expression, which refers to the way in which a lover embellishes and idealizes his beloved one, and continually discovers in her new perfections and greater charms.

\section{"Ecstasy", "dizziness" and "being at a loss"}

In Djado Sékou's narratives, the body may become metaphoric. In "Gorba Dicko", the superb images the storytellers use to describe the female body perfectly illustrate this. Perceived in its concreteness, the female body becomes, in the griot's mouth, a strong incentive for the warrior. Returning home with his booty, Gorba Dicko is attacked by Touareg men. He asks the kidnapped woman accompanying him to do him a favour:

I would like you to stand by this tree

and lower your cloth,

so as to reveal Satan's two nephews. 
(...) Lower your cloth

so as to reveal your two breasts.

When our eyes meet,

smile to me,

this is the support I ask of you.

She smiled, with her breaths outside her cloth. ${ }^{12}$

Such poetic images are still taboo in Zarma society: the breast, the curve of the waist, and the charming shape of the arms, and the sight of a woman's hair are recurrent in Djado Sékou's narratives. The female body and even the female genitalia are the griot's sources of inspiration and reveries, and seem to be synonymous with flights of fancy. Indeed, in Djado Sékou's narratives, loving sentiments, the bodily presence of the loved one, and especially lovemaking, provoke a feeling of a journey on earth, and perhaps in the air. They create a sensation of "dizziness" or of "being at a loss" - a sensation arising both from love and the sexual act, but also from fantasising.

Sombo and Lobbo are courting one another,

they are courting one another

to the point that they cannot do without one another.

One night, they chatted till late.

Lobbo Soga took Sombo's hand,

Satan entered their eyes,

Suddenly Lobbon began to weep. ${ }^{13}$

Lobbo weeps, tortured by desire. Society is categorical and will not allow her to experience what she desires. As they are not yet united in marriage, the two youths must wait before they can satisfy their desire.

Djado Sékou presents both the body and daydreams about the beloved and fantasies about his/her body. Awli's beautiful erotic fantasy best illustrates a story where sensuality is intermingled with daydreaming. Djawando imagines himself with Awli's body beside him. In contact with fire, he feels the presence of Awli's body, and slips into fantasy. He has sex with the girl's naked dream-body. His erotic fantasies of Awli's body are so powerful, the fire of desire so strong that Djawando's seems to appear-his presence a fantasy yet oh so real; she sees Djawando nimble hands playing the moolo, accompanied by the handclapping of his lover.

In this rich and suggestive description where Awli's imagination and sensuality reinforce one another and amplify her desire, fire plays 
a crucial role. Ambivalent in essence, a source of life and death, richly symbolic, fire also relates to reveries and love, as Bachelard (1991) shows in his work on L'eau et les rêves (Water and dreams). The metaphor of fire is recurrent in literature as well as in everyday language. In the works of romance writers and theoreticians, it accounts for loving sentiments and burning desire, consuming and even sometimes destroying the individual who falls prey to it. ${ }^{14}$ For instance, Julia Kristeva writes about "conflagrating love" (d'amour embrasement) or else, "love [that] never inhabit us without burning us" (l'amour ne nous habite jamais sans nous brûler, Kristeva, 1983: 11-12). In the $17^{\text {th }}$ century, the "fires of love" were so present is the rhetoric that the original metaphor was soon forgotten, and eventually disappeared. The texts of contemporary writers, especially Djado Sékou's narratives, try to restore the metaphor. Without overusing it, Djado Sékou resorts to the metaphor of fire and weaves a semantic network involving terms such as "flames", "fire", "fever", "to consume" and "to explode". The metaphor is discrete, and it expresses desire while suggesting a "food of loss". This may represent love, especially absolute love, which, like fire, is capable of ravaging and destroying.

Thus, twice Djado Sékou evokes the burning that the couple experiences: the fire burning the hut and inside Awli and her fiancé. This fire is, according to traditional symbolism, synonymous with purity or purification. Here it seems to comply perfectly with the young girl's taste for absolutes which shows in her setting fire to the four corners of the hut. We see her absorbed in contemplating the fire. Then she rediscovers the way to happiness in the glow of the burning stems of the hut's thatch. Equally, the dancing of the vanishing flames may indicate the intermittent movements of the desire inhabiting Awli and Djawando, lying down inside the hut, by the fire, in shared intimacy. The two lovers thus gradually discover that total union with the loved one, which Barthes (1977: 267) describes as fruitage union (the fruition of love) is an ideal rarely reached or grasped. After the dream of fusion and harmony, the sensation of journeying, ecstasy, and fulfilment, comes the discovery of the violence of love. The forcefulness and precision of the terms used, for example, the coiling up of the body, the laying position beside her, and the interlacing of the legs, which suggest a dream of fusion or a dream of total union with the loved one. This is more a dream of a body union than an adhesion or an attempt to share the "same skin" with the loved one or with her/his image. 


\section{Journeys}

Awli's sensual drift in the burning hut suggests that love may be a journey, a journey of the heart, the body, and the senses, towards an elsewhere, which is synonymous with novelty and feeling of strangeness. Awli leads Djawando into a journey. She leads him into a "country", and infuses him with a sense of infinity while at the same time giving roots to his life.

The journey involves a variety of places, conducive to intimacy and sexual activity, places in which the lovers may hide or whip up their sensuality. Djado Sékou addresses the theme of love as a journey into an imaginary and sensational world, an opening into a new universe. In "Awli Djawando", he describes the extent to which Awli's love for Djawando depends on complicity, games, and imagination. Here is how Awli defines her conception of love to Djawando:

You love me.

When you love someone,

Bad behaviour does not discourage you, you take patience,

you tell yourself, this will not last forever;

Now it is my turn to prove my love for you!

What worth is a man's love for a woman

if it is not mutual? ${ }^{15}$

Awli and Djawando loved each other wherever they were; they overcame all the difficulties they met in the bush, in the burning hut, etc. Theirs was a wonderful honeymoon journey.

In Djado Sékou's narratives, women often embody "transport" and "rapture". They are an invitation to journeying. This is the case with the black woman in "Gorba Dicko", where she appears shrouded with mystery. The woman represents for the hero, Gorba Dicko, the attraction of the unknown. She gives rise to a field of possibilities, a different world. She is the one that, along his tumultuous youth, the hero must steal from the bloodthirsty king and then marry. In love, the partner is sometimes an opponent and other times a rival, who must be fought or trapped, vanquished or transformed into a prey, solely for the sake of satisfying the senseless and painful need to possess. Here we may note the presence of warlike vocabulary, beside the images related to abduction or theft, capture and hunting. Both the vocabulary and images imply violence, brutality in love relations, and constitute the foundation of Djado Sékou's poetry. 
Western literature as well as everyday language establishes a close link between love and conflict. In antiquity, poets used a set of warlike metaphors to describe love and its effects. Even discounting Freudian theories, this seems to confirm "the natural, physiological link between sexual instincts and battle instincts." Rougemont (1979: 264) clarifies this when he explains that "since the $12^{\text {th }}$ and $13^{\text {th }}$ centuries, love language has enriched itself by borrowing expressions from the art of battle, military tactics." 16 This seems to prove once more that the "the war instinct and eroticism are fundamentally linked" to the point of shaping our imagination and being the source of the warlike love language that we use, when for instance we talk of love conquest or strategy. In literature, this language regains its full force and shows itself to advantage through the vocabulary and network of metaphoric images, which poets and novelists employ. Djado Sékou's work is rich with images and comparisons based on battle and opposition between a man and woman in love. In the couples represented in Djado Sékou's narratives, physical force is the prerogative of man, who has "violent" and "furious" arms and legs as well as "brutal movements", while for the woman it has "devastating taste". Physical force transforms her and her body into "a field of ravage". In "Bubu Ardo Galo" for instance, Takaldé Waldé falls a victim of El Hadj Umaru's followers.

In "Gorba Dicko", Djado Sékou contemplates this man in full strength as a man who harbours violence, while the woman "vainly" tries to fight or patiently prepares her body for violence, a violence which will leave her "twitching". Gorba Dicko forces the woman to leave her husband:

Listen! said Gorba Dicko to the princess, stop shuddering on your chair.

Your spouse's life will be spared

on the condition that you declare that you

repudiate him for ever on this earth as well as in the life after

Let him become a father to you! ${ }^{17}$

And, understand that I will behead you if you hesitate to say this.

Repeat it without hesitating. ${ }^{18}$

Through the vocabulary and images he selects, Djado Sékou tries to express unspeakable brutality and savagery, and thereby reveals the power of language. He portrays a spectacle of devastation matching the shock or intensity of the battle taking place between man and woman, henceforth displaced from the sweet reveries characterising the inception of love. 
In this duel or love battle that the storyteller narrates, in this unbalanced tussle between strenght and violence, on one hand, and weakness and fragility on the other, it appears that man seeks triumph or victory and then the "pleasure" of the victor who promptly subjugates the woman. It is therefore not surprising that in Djado Sékou's narratives, physical love is portrayed from the perspective of power relations, battle, and even war. This explains why a woman frequently sees a man as "a fearful or merciless adversary", an enemy, rather than a serving knight. Man and woman are two "fighters" who use tricks and plots, build stratagems, and deploy arsenals to dominate, conquer, or escape one another.

To express the ardour and tumult of love and passion, desire and pleasure, as well as their destructiveness and brusqueness, Djado Sékou invents images or metaphors evoking ravage and devastation. From the tyrant kings and cyclones referred to in "Lobbo Soga" and "Gorba Dicko", to the cataclysm of fire described in "Awli Djawando", love very often appears in the shape of catastrophic sentiment. We discover the brusqueness, violence and destructiveness of the event or sensation experienced. In "Awli Djawando", Djado Sékou refers to a fire ravaging the body of the lovers and describes the pleasure arising in the form of an abominable devastation, which will never be mended. The terms "ravage" and "devastation", and "irreparable" give a measure of the "irretrievable mess". It is precisely this feeling of irremediability that the inhabitants experience when they hear the bodies of the lovers "exploding" in the burnt hut.

Love, the violence of love emotion and the forces at work inside the body, such as desire and pleasure, have no equivalent elsewhere except in the power and outburst of the natural elements that provoke ravages and devastations. Thus, the use of these elements in the narratives express, less the happiness of the individual and the fulfilment of the body than the destructive force residing in man's heart and in love. This inherent negativity, which may rise out of or burst from unsatisfied desire or a lack felt in a love relation, makes way for "misfortunes" and helps unveil a different dimension of the poetry of dreams and reveries.

Fed by the sweet and voluptuous reveries of the inception of love, the bright side of dream poetry constitutes a source of literary wealth and opens the field of dream to the literary work. Nevertheless, love has a darker dimension, which corresponds to a painful experience of characters that, as a result, can no longer enjoy the power of fantasy or 


\begin{abstract}
the seduction of reveries. Storytellers continue to imagine, invent, and elaborate their creations in the form of dreams, whereby they ponder on the difficulties inherent in love, in knowing and understanding the loved one fully, and in attaining the long-lasting fulfilment and happiness with him/her.
\end{abstract}

Translated by Amadou Bissiri.

Le texte original en français est disponible sur www.letterkunde.up.ac.za

\title{
Notes
}

1. "un poème qui organise le parcours du héros en fonction des variations d'un destin capricieux, qui l'expose à des rencontres et à des séparations, et fait une place au merveilleux et à l'amour" (Suard, 1993: 80).

2. Djado Sékou is one of Niger's most celebrated griots. He has a repertoire of about fifteen epic narratives, seven of which have been transcribed, translated and published in the second volume of my Habilitation Research Report (see Tandina, 2003).

3. “à la peau si claire, aux cils tellement noirs, au cou tellement gracieux, à la taille si bien faite, au bassin si parfait, et aux yeux si blancs, et non pas ces yeux rouges comme ceux des pigeons."

4. "Labdedjo" is an epic narrative by the celebrated griot Tinguizi. (See Tandina [2003] for a translation.) All griot narratives quoted are taken from Tandina (2003).

5. "Elle prit le couteau/ et se le planta entre les seins./ Elle se le planta si fort/ que le couteau la transperça de part en part./ Puis à l'aide de ses deux mains,/ elle ôta le couteau de ses seins/ et le replongea sous le nombril./ Elle ne parvint plus à le retirer./ Elle s'écroula./ Avant que les cavaliers ne vinssent à son secours,/ Elle était déjà tiède./ On l'ensevelit avec son mari dans une même tombe à Koola."

6. In the original Songhay-Zarma language: "Nan kan Maamudu Jaawando na ce hinka salle car bon seezo ra/ Jirbi haako me a me mana cey zumandi car bon/ sonku a ma tunuyan miila."

7. "une personne qui aime est occupée par l'image de ce qu'elle aime assidûment et sans interruption" Stendhal (1989: 311).

8. "Da i fatta no Baïdari ca zuru lew-lew/ Ga ne I ma ka ga di hari hinza kan ga boori/ Di naé mo dan Sambo ga/ Ni ma ye Loobo ga/ Din na moo ka Lobbo/ Ma a ye hare ka mo dan baryo ga/ Kala i ka ga to fu."

9. "I di ga faakarey kala alfazaro koymaanu,/ A ne a ma moola jeeri,/ A na moola jerri,/ Kocia kani ga hangasu,/ Ana taafa me wene feeri ga furu ne hare,/ Ana wene furu ga furu ne hare,/ A ne aro ma nga guna hala nga ya wandiyo no wala nga ya waykuuru no./ Aro tun ga goy hala a boori./ A ka gar moday wandiyo cimi-cimi/ Kohum!/ A ne ase: 'ni bay ni dii hankan alborofo kulu mandii ceefo wala,'/ A ne 'ciimi ni ga ti wandiyo hala a go idunya bon ba!'”

10. "Jawandayze wayboro fo no/ Kan te wangaari/ Nan kulu kan a ma/ I na kayey nda baabey gaarey/ Nangey din kulu no a ton."

11. "A binde za nankan sambo na kambo sambu ga dake/ Lobbo Soga bon/ Kan a na kamba mooru/ A ne wone ya da manti Jinni kambe no/ Kulu saytani kambe no/ Wala Sombo nda a ga funa a kambe no/ Day I za ga care musey daari wano bon/ Kala alfazaro manu."

12. "Ay si ba kala ni ma goro ne tuuro tigiso ga/ Ni ma ni zaara dumbu cante/ ga ibilisi waymeyze hinka ka taaray/fofey day no a ga ba a ma i ka taaray/fofe hinka/ Saaya kulu kan ir mo hinkote i taaci/ Kala yi'n hinjey garu taarey/ Wo kan ni ga ay kambuza nda no ya/ A ka ga haru fofey go ga kay a se."

13. "I dira ga care arwasey i dira ga care arwasei/ kala afo kulu si goro a man di afo/ han kan ga te bine I go ga faakarey kala cino yay/Lobbo Soga bine ana Sambo Soga gayi a na gayi/ Iblis na a di kan a go ga a guna/ Day zurku, a hin."

14. The meaning of fire as linked with desire or more generally with sexuality, finds its origins in the reference to the "first technique used to produce fire through rubbing". The back and forth movements suggest a sexual act (Chevalier \& Gheerbrant, 1982: 437). The symbolism of fire has multiple meanings (see Chevalier \& Gheerbrant, 1982: 435-438; Bachelard, 1989). 
15. "Wandiya ne a se: 'ni no ga ba ay?'/ hala boro ga ba boro,/ 'ba a gonda dà laalo ni ga hin a suuru'/ zama ni si ne kala a ga hani ga ban a ga/ 'amma ay no ga ni cabe baagasinay'/ Alboro baagasinay si hay kulu hanse wayboro do,/ hala manti waybora no ga ba ra."

16. "à partir des XIIe et XIIIe siècles (...) le langage amoureux s'(est) enrichi de tournures (...) empruntées d'une façon très précise à l'art des batailles, à la tactique militaire" (Rougemont, 1979: 264).

17. If the woman obeys the order and declares her husband her father, she will then be committing incest in going back to him as a spouse.

18. "Gorba Dikko A ne bonkoono izo wando se guna! Nan ni jijiriyan seezo ra yan./ Haya kulu si ni kurnyo wo ka ay ce wo cire/ Kala ni ma ne/ ni na a harram ndunnya ra ga guna alcioma./ A ma te ni se ni baaba;/ Da ni me gasi ga sanno wo ci mo ay ga bono ka./ A ma a ci lakkal kanay ra."

\section{Bibliography}

Primary sources: oral narratives

Djado, Sékou. 1974a. Awli Djawando. Niamey: The Institute for Research in Social Science.

—. 1974b. Bubu Ardo Galo. Interview.

1974c. Gorba Dicko. Interview.

1974d. Hamma Bodedjo Paaté. Interview.

1974e. Sombo Soga. Niamey: The Institute for Research in Social Science.

Djéliba, Badjé. 1974. Garba Mama. Niamey: The Institute for Research in Social Science.

Tinguizi. 1974. Labdedjo. Niamey: The Institute for Research in Social Science.

\section{Secondary sources}

Bachelard, Gaston. 1942. L'eau et les rêves. Paris: José Corti, 19. 1989 [1949]. La Psychanalyse du feu. Paris: Gallimard.

Barthes, Roland. 1977. Fragments d'un discours amoureux. Paris: Le Seuil.

Brochier, Jean-Jacques. 1994 [1967]. Mon siècle par Aragon. La Magazine littéraire 322: 34-41.

Chevalier, J. \& Gheerbrant, A. 1982. Dictionnaire des Symboles. Paris: R. Laffont.

Kristeva Julia. 1990 [1983]. Histoires d'amour. Paris: Gallimard.

Rougemont de, D. 1979. L'Amour et l'Occident. Livre I. Paris: Plon, coll. "10/18”.

Suard, François. 1993. La chanson de geste. Paris: PUF.

Sur, Jean. 1966. Aragon, Le Réalisme de l'amour. Paris: Ed. du Centurion.

Stendhal [ps. Marie-Henri Beyle]. 1989 [1822]. De l'amour, "Appendix". Paris: Gallimard-Flammarion.

Tandina, Ousmane. 2003. L'Epopée au Niger à travers quelques récits de griots. Amiens: Jules-Vernes University. 